\title{
PENGARUH KEPUASAN KERJA, KOMITMEN DAN KINERJA TERHADAP PENGEMBANGAN PEGAWAI PADA BADAN PENGELOLAAN KEUANGAN DAN ASET DAERAH KABUPATEN TANAH BUMBU DI BATULICIN
}

\author{
Aulia Farsihat Farinduri \\ Sekolah Tinggi Ilmu Ekonomi Pancasetia Banjarmasin \\ Jl. Ahmad Yani Km. 5.5 Banjarmasin \\ aulia_farsihat_farinduri@gmail.com
}

\begin{abstract}
Abstrak: Tujuan penelitian ini adalah untuk menganalisis : (1) pengaruh Kepuasan Kerja terhadap pengembangan pegawai, (2) pengaruh komitmen pegawai terhadap pengembangan pegawai, (3) pengaruh kinerja pegawai terhadap pengembangan pegawai, (4) Kepuasan Kerja, Komitmen dan Kinerja berpengaruh secara simultan terhadap pengembangan pegawai pada Badan Pengelolaan Keuangan dan Aset Daerah Kabupaten Tanah Bumbu di Batulicin. Metode penelitian yang peneliti gunakan adalah Eksplanatori. Populasi penelitian ini adalah seluruh Pegawai Badan Pengelolaan Keuangan dan Aset Daerah Kabupaten Tanah Bumbu sebanyak 40 orang secara Total Sampling. Pengumpulan data dalam peneiitian ini melalui Kuesioner, Wawancara, Dokumentasi dan Observasi, Analisis data dilakukan secara kuantitatif melalui model regresi dengan menggunakan aplikasi SPSS for windows versi 20.0. Hasil penelitian menunjukkan : (1) Secara simultan dari persamaan regresi dapat dikemukakan bahwa Kepuasan Kerja $\left(\mathrm{X}_{1}\right)$, Komitmen $\left(\mathrm{X}_{2}\right)$ dan Kinerja $\left(\mathrm{X}_{3}\right)$ terhadap Pengembangan Pegawai menunjukan pengaruh yang signifikan karena Berdasarkan hasil uji $\mathrm{F}$ diketahui bahwa $\mathrm{F}$ hitung $>\mathrm{F}$ Tabel. Atau dengan angka $\mathrm{F}$ hitung 19.899> $\mathrm{F}$ Tabel 2.45 sehingga hipotesis yang mengatakan terdapat pengaruh yang signifikan secara simultan terbukti kebenarannya. (2) Secara parsial dari persamaan regresi Kepuasan Kerja $\left(\mathrm{X}_{1}\right)$ dan Komitmen $\left(\mathrm{X}_{2}\right)$ dan Kinerja $\left(\mathrm{X}_{3}\right)$ terhadap Pengembangan Pegawai berdasarkan hasil uji $\mathrm{t}$ diketahui bahwa $\mathrm{t}$ hitung $>\mathrm{t}$ Tabel. Dengan angka masing-masing untuk Kepuasan Kerja $\left(\mathrm{X}_{1}\right)=4.644$, Komitmen $\left(\mathrm{X}_{2}\right)=-1.332$ dan dan Kinerja $\left(\mathrm{X}_{3}\right)=4.128$ terhadap Pengembangan Pegawai terbukti kebenarannya, serta (3) Kepuasan Kerja mempunyai pengaruh dominan terhadap Pengembangan Pegawai setelah dibuktikan melalui besarnya Nilai $\mathrm{t}$ hitung atau Kepuasan kerja $\left(\mathrm{X}_{1}\right)=4.644$ dapat dibuktikan kebenarannya karena dari keseluruhan faktor-faktor yang diteliti dengan angka paling besar.
\end{abstract}

Kata kunci : Kepuasan Kerja, Komitmen, Kinerja, Pengembangan Pegawai 


\section{Latar Belakang}

Salah satu upaya yang dapat dilakukan untuk meningkatkan kemampuan pegawai, adalah dengan menciptakan iklim yang dapat memotivasi pegawai untuk meningkatkan kinerjanya. Untuk itu, diperlukan pemahaman tentang kebutuhan atau keinginan para pegawai. Salah satu kebutuhan atau keinginan para pegawai, ialah mendapat kesempatan untuk meniti karier dengan baik. Dengan demikian, dapat dikatakan bahwa guna memotivasi pegawai meningkatkan kinerjanya, perlu jaminan karier yang jelas, dalam arti setiap pegawai yang memperhatikan kinerja baik, akan memperoleh kesempatan meningkatkan kariernya dengan baik pula. Sebaliknya, pegawai yang kurang berprestasi tidak akan mendapat kesempatan peningkatkan karier melalui pengembangan Aparatur.

Namun kenyataan yang dijumpai di lapangan memperhatikan keadaan yang kurang sesuai dengan apa yang telah diuraikan di atas. pengembangan pegawai melalui diklat yang diharapkan dapat meningkatkan kinerja pegawai Badan Pengelolaan Keuangan dan Aset Daerah Kabupaten Tanah Bumbu pada umumnya masih rendah. Rendahnya kinerja tersebut ditandai dengan belum mantapnya pola pegawai sehingga tidak ada kepastian yang menjamin pengembagan pegawainya. Informasi-informasi sebagaimana diuraikan, memperlihatkan lemahnya pola pegawai di satu sisi, dan rendahnya kompetensi di sisi lain yang ditandai dengan rendahnya prestasi pegawai. Keadaan yang sama terjadi juga pada pegawai Badan Pengelolaan Keuangan dan Aset Daerah Kabupaten Tanah Bumbu Pola pendidikan dan pelatihan menyangkut pegawai terlihat kurang memberi kejelasan dan kepastian bahwa, kinerja merupakan dasar utama dalam pengembangan pegawai. Pada saat yang sama juga, derajat motivasi berprestasi para pegawai belum pada taraf yang mengembirakan.

Banyak pemikiran tentang upaya memotivasi pegawai untuk mencapai kinerja yang tinggi, namun sebagian besar melihatnya dari segi ekonomi yaitu perbaikan dalam tingkat penghasilan, khususnya gaji. Karena itu, yang paling sering disarankan untuk memotivasi pegawai agar bisa mencapai kinerja yang baik adalah perbaikan penghasilan atau gajinya. Pemikiran ini, seakan-akan mengasumsikan bahwa kebutuhan pegawai hanya satu yakni uang. Bahkan, jika pegawai meningkat maka kebutuhan ekonominya (uang) juga akan terpenuhi, sebab setiap peningkatan jabatan akan diikuti dengan peningkatan penghasilan (Gaji, tunjangan dan fasilitas lainnya). Hal ini dikemukakan oleh Siagian (2012 : 169) bila seseorang pegawai dipindahkan dari satu pekerjaan ke pekerjaan lain yang ditanggung jawabnya lebih besar, tingkatannya dalam hierarki jabatan lebih tinggi, maka penghasilannya pun akan bertambah. Dengan kata lain, jika orang dipromosikan ke jabatan yang lebih tinggi, maka penghasilannya akan meningkat.

Sebagaimana salah satu aspek komitmen organisasi yang dikemukakan oleh Luthans (2012:21) adalah kerelaan untuk bekerja semaksimal mungkin demi kepentingan organisasi. Ada beberapa alasan mengapa organisasi harus melakukan berbagai usaha untuk meningkatkan derajat komitmen organisasi dalam diri pegawai. Pertama, semakin tinggi komitmen pegawai, semakin besar pula usaha yang dilakukannya dalam melaksanakan pekerjaan. Kedua, semakin tinggi komitmen pegawai, maka semakin lama pula ia ingin tetap berada dalam organisasi.

Dengan kata lain, jika pegawai mempunyai komitmen organisasi yang tinggi, maka ia tidak berniat meninggalkan organisasi (Mowday, Porter \& Steers, 2012:21). Porter dalam Thoha, 2012:21) mengatakan bahwa komitmen organisasi didefinisikan sebagai pengidentifikasian 
dan keterlibatan dari seorang individu terhadap organisasi tertentu. Hal ini sejalan dengan pendapat Mowday, Porter, dan Steers (dalam Thoha, 2012:12). yang mendefinisikan komitmen organisasi sebagai sifat hubungan antara pekerja dan organisasi. Individu yang mempunyai komitmen tinggi terhadap organisasi dapat dilihat dari keinginan kuat untuk tetap menjadi anggota tersebut, kesediaan untuk berusaha sebaik mungkin demi kepentingan organisasi tersebut, dan kepercayaan akan dan penerimaan yang kuat terhadap nilai-nilai dan tujuan organisasi.

Komitmen kerja sebagai keinginan kuat untuk tetap sebagai anggota organisasi tertentu, berusaha keras sesuai keinginan organisasi dan penerimaan nilai dan tujuan organisasi. Dengan kata lain, ini merupakan sikap yang merefleksikan loyalitas karyawan pada organisasi mengekspresikan perhatiannya terhadap organisasi dan keberhasilan beserta kemajuan yang berkelanjutan.

Oleh karenanya komitmen kerja sebagai rasa identifikasi (kepercayaan terhadap nilai-nilai organisasi), keterlibatan (kesediaan untuk berusaha sebaik mungkin demi kepentingan organisasi) dan loyalitas (keinginan untuk tetap menjadi anggota organisasi yang bersangkutan) yang dinyatakan oleh seorang pegawai terhadap organisasinya. Steers berpendapat bahwa komitmen organisasi merupakan kondisi dimana pegawai sangat tertarik terhadap tujuan, nilai-nilai dan sasaran organisasinya. Komitmen terhadap organisasi artinya lebih dari sekedar keanggotaan formal, karena meliputi sikap menyukai organisasi dan kesediaan untuk mengusahakan tingkat upaya yang tinggi bagi kepentingan organisasi demi pencapaian tujuan. Berdasarkan definisi ini, dalam komitmen organisasi mencakup unsur loyalitas terhadap organisasi, keterlibatan dalam pekerjaan, dan identifikasi terhadap nilai-nilai tujuan organisasi.

Komitmen organisasi merupakan keterlibatan seluruh karyawan yang ada pada suatu organsisasi dalam aktifitasnya untuk mencapai keberhasilan suatu organisasi yang didukung oleh sikap loyalitas, pemahaman dan kepercayaan terhadap nilai-nilai organisasi. Komitmen organisasi merupakan sikap patuh dan setia seorang karyawan terhadap organisasinya dengan memberikan kontribusi yang tinggi untuk kemajuan organisasinya. Sikap patuh tersebut ditunjukkan dengan mengikuti segala peraturan yang berlaku dalam organisasi, sedangkan sikap setia ditunjukkan dengan tidak berkeinginan untuk pindah dari organisasi tempatnya bekerja dan akan berusaha untuk mencapai tujuan organisasi.

Menurut Manullang (2001:1194) kepusan kerja merupakan pekerjaan yang dilakukan oleh seorang manajer memberikan inspirasi, semangat dan dorongan kepada orang lain. Dalam hal ini karyawan untuk mengambil tindakantindakan, pemberian dorongan ini bertujuan untuk menggiatkan orang-orang karyawan agar mereka bersemangat dan dapat mencapai hasil sebagaimana dikehendaki dari orang-orang tersebut.

Dengan adanya kepuasan kerja dapat memberikan dorongan kebutuhan dari dalam diri pegawai yang perlu dipenuhi agar pegawai tersebut dapat menyesuaikan diri dengan lingkungan organisasinya serta dapat bergerak untuk mencapai tujuan bersama. Pemberian motivasi kepada para karyawan merupakan kewajiban para pimpinan, agar para karyawan tersebut dapat bekerja dengan maksimal dan menghasilkan kinerja yang baik. Untuk itu seorang pimpinan perlu memperhatikan dan memahami perilaku bawahan, memahami tingkat kebutuhan 
setiap orang berbeda-beda, pemberian motivasi mengacu pada orang, harus dapat memberi keteladanan. Semua itu perlu diperhatikam agar pemberian motivasi dapat berhasil seperti yang diharapkan.

Katili (2010:54) juga berpendapat bahwa untuk mengembangkan sumber daya manusia, baik pemerintah maupun swasta, diperlukan adanya pengalaman kerja. Pengalaman kerja sarat dengan pemahaman bekerja menurut masa kerja karyawan, tingkat kesenioran, posisi jabatan yang dimiliki dan kepemimpinan yang pernah diduduki.

Byars dan Rue (2008 : 216) mengatakan bahwa kinerja merupakan hasil dari usaha karyawan yang dipengaruhi oleh kemampuan dan persepsi peran (tugas). Dengan demikian, dalam situasi tertentu kinerja dapat dilihat sebagai hasil dari hubungan antara usaha, kemampuan dan persepsi tugas. Kinerja adalah suatu hasil yang telah dicapai dalam mencapai tujuan organisasi yang dilaksanakan sesuai dengan tugas dan tanggung jawab yang telah dibebankan oleh setiap individu atau kelompok

Sehubungan dengan hal tersebut diatas guna meningkatkan kualitas Sumber Daya Aparatur dan mengembangkan kepribadian sesuai tuntutan masyarakat yang dilayani, sangatlah diperlukan adanya produktivitas kerja pegawai yang mampu memberikan kontribusi yang besar terhadap pelayanan dari aparatur pemerintah tersebut pada setiap kesempatan pengembangan karier dan profesi sesuai tuntutan tugas dan tanggung jawab yang dibebankan untuk memelihara kontuinitas pembinaan Aparatur Pemerintah termasuk Pegawai pada Badan Pengelolaan Keuangan dan Aset Daerah Kabupaten Tanah Bumbu di Batulicin.

Keberhasilan dalam pembinaan pegawai tersebut tidak hanya terletak pada pihak pimpinan saja, tetapi pihak pegawai juga harus benar-benar berperan aktif sehingga pada gilirannya akan melahirkan Aparatur Negara yang benarbenar sesuai dengan yang diharapkan. Meskipun demikian pembinaan yang dilakukan secara terus menerus bukan menjadi jaminan berhasilnya menciptkan Aparatur Negara yang baik, hal ini erat kaitannya dengan unsur kemauan dari bawahan itu sendiri, peranan pimpinan disini hanya untuk mengarahkan guna menjamin penyelenggaraan tugas-tugas pemerintahan, pembangunan dan pelayanan masyarakat secara berdayaguna dan berhasil guna.

Dari berbagai pegawai yang terjadi didapat bahwa prestasi kerja Pegawai di Badan Pengelolaan Keuangan dan Aset Daerah Kabupaten Tanah Bumbu di Batulicin masih jauh dari memadai dan buruknya prestasi kerja tersebut menunjukkan bahwa produktivitas kerja pegawai merupakan dilema yang sering terjadi pada birokrasi saat ini banyak menjadi sorotan. Adanya tanggapan terhadap prestasi kerja aparatur pemerintah yang belum menunjukkan kapabilitas yang tinggi serta tidak profesional dan tidak berkualitas dalam menjalankan tugasnya, hal ini dapat dilihat melalui berbagai penyimpangan yang terjadi dalam birokrasi, seperti disiplin kerja yang menurun berakibat pada tingkat kepercayaan (trust) masyarakat terhadap pelayanan kerja.

Tanpa mengabaikan arti pentingnya uang sebagai alat motivasi, maka kebutuhan pegawai akan peningkatan karier dapat dijadikan sarana untuk memotivasi para pegawai mencapai kinerja yang baik. Ini mengandung makna bahwa, karier berkaitan dengan kepuasan individu, baik dalam organisasi maupun dalam kehidupannya. Artinya, bila orang mendapat jaminan karier yang baik, maka pegawai akan puas dan bekerja dengan sungguh-sungguh. Sebaliknya, bila tidak ada jaminan karier 
yang baik maka orang rnenjadi tidak puas dan sulit diharapkan untuk bekerja dengan baik Karena itu, pola pengembangan menjadi sesuatu yang sangat penting. Peningkatan karier mempunyai dimensi yang lebih luas dari sekedar pemenuhan ekonomi (uang). Peningkatan karier, selain berkaitan dengan pemenuhan kebutuhan ekonomi, juga berkaitan dengan kepuasan kerja, identitas diri, prestise, kenyataannya sedikit sekali perhatian yang diberikan terhadap permasalahan ini.

Belum mantapnya pengembagan pegawai pegawai Badan Pengelolaan Keuangan dan Aset Daerah Kabupaten Tanah Bumbu Kabupaten Tanah Bumbu dam melaksanakan tugasnya, pada kenyataan bahwa dalam beberapa hal masih terdapat hambatan-hambatan yang antara lain disebabkan oleh rendahnya pengembangan sumber daya manusianya baik menyangkut kualitas maupun kuantitas yang dapat dilihat dari pengernbangan sumber daya manusia yang menyangkut jabatan, kegiatan kerja serta keahlian yang dimiliki. Disamping itu efektivitas kerja organisasi yang menyangkut pendidikan, pengalaman serta kemampuan yang dimiliki oleh pegawai Kinerja Kabupaten Tanah Bumbu juga merupakan hambatan bagi pelaksanaan kerja pegawai, sehingga kinerja yang ingin dicapai belum memenuhi sasaran sesuai perencanaan target/sasaran, produktivitas serta efisiensi waktu pelaksanaan kerja pegawai pegawai Badan Pengelolaan Keuangan dan Aset Daerah Kabupaten Tanah Bumbu.

Adapun permasalahan yang ditemui setelah dilihat dari fenomena yang ada dilapangan secara faktual, meliputi :

1. Pengembagan pegawai Sumber Daya Manusia yang seharusnya dilakukan secara berjenjang dari kedudukan pejabat atau pimpinan terendah belum dilaksanakan dengan baik.
2. Efektivitas kerja yang kurang mendukung pelaksanaan kegiatan yang berkaitan dengan sasaran dan tujuan terlihat dengan adanya duplikasi kerja administrasi pada masing-masing bagian.

3. Semakin ketatnya kompetensi untuk meningkatkan Profesionalitas kerja bawahan, sehingga kesempatan untuk mengembangkan karier pgawai.

4. Lemahnya kualitas SDM untuk melaksanakan kegiatan pengembangan bagi pegawai yang memiliki kinerja yang baik.

Berdasarkan latar belakang masalah maka dapat dirumuskan masalah penelitian sebagai berikut :

1. Apakah Kepuasan Kerja berpengaruh secara parsial terhadap pengembangan pegawai pada Badan Pengelolaan Keuangan dan Aset Daerah Kabupaten Tanah Bumbu di Batulicin?

2. Apakah Komitmen pegawai berpengaruh secara parsial terhadap pengembangan pegawai pada Badan Pengelolaan Keuangan dan Aset Daerah Kabupaten Tanah Bumbu di Batulicin?

3. Apakah Kinerja pegawai berpengaruh secara parsial terhadap pengembangan pegawai pada Badan Pengelolaan Keuangan dan Aset Daerah Kabupaten Tanah Bumbu di Batulicin?

4. Apakah Kepuasan Kerja, Komitmen dan Kinerja berpengaruh secara simultan terhadap pengembangan pegawai pada Badan Pengelolaan Keuangan dan Aset Daerah Kabupaten Tanah Bumbu di Batulicin?

\section{Kajian Literatur}

1. Kepuasan Kerja $\left(X_{1}\right)$

Kepuasan kerja sebagai kombinasi kondisi psikologis, fisiologis dan lingkungan yang menyebabkan orang berkata saya puas dengan 
pekerjaan saya. Maksudnya, kepuasan kerja adalah kondisi dimana individu menyukai pekerjaannya. Dengan demikian kepuasan kerja mencerminkan perasaan seseorang terhadap pekerjaan yaitu cara pandang pegawai terhadap pekerjaan mereka. Hasibuan, Melayu S.P (2012:203) mengemukakan faktorfaktor yang mempengaruhi kepuasan kerja yaitu antara lain :

a. Balas jasa yang adil dan layak

b. Penempatan yang sesuai dengan keahlian

c. Berat ringannya pekerjaan

d. Suasana dan lingkungan pekerjaan

e. Peralatan yang menunjang

f. Motivasi pimpinan dalam kepemimpinannya

2. Komitmen $\left(\mathrm{X}_{2}\right)$

Komitmen adalah melibatkan keterikatan individu terhadap pekerjaannya. Komitmen kerja merupakan sebuah variabel yang mencerminkan derajat hubungan yang dianggap dimiliki oleh individu terhadap pekerjaan tertentu dalam organisasi. Menurut Glickman (2010:52) komitmen kerja pegawaitersebut dipengaruhi unsur-unsur sebagai berikut.

a. Penggunaan waktu dalam tugas

b. Perhatian terhadap tugas

c. Perhatian terhadap publik

3. Kinerja $\left(\mathrm{X}_{3}\right)$

Kinerja adalah suatu hasil kerja yang dicapai seseorang dalam melaksanakan tugas yang dibebankan kepada didasarkan atas kecakapan, pengalaman dan kesungguhan waktu. Menurut Simamora (2010 : 132-134) faktor-faktor yang mempengaruhi kinerja dapat dilihat dari indiktorindikator sebagai berikut :
a. Kualitas Kerja :
b. Kuantitas kerja
c. Pengetahuan
d. Keandalan
e. Kehadiran
f. Kerjasama

4. Pengembangan pegawai (Y)

Pengembangan pegawai adalah suatu usaha yang penting dalam organisasi oleh karena dengan pengembangan inilah organisasi akan dapat maju dan berkembang. Pegawai yang bermutu adalah mereka yang mempunyai kecakapan dan kemampuan untuk menyelesaikan suatu pekerjaan yang dibebankan kepadanya serta dapat memelihara dan meningkatkan kecakapan dalam kemampuan itu secara teratur dan pasti. Organisasi sangat mendambakan adanya pegawai yang demikian, oleh karena itu dengan melalui berbagai cara dan usaha. Menurut Moenir (2012 : 16) kegiatan yang dapat dilakukan oleh suatu organisasi untuk mengembangkan pegawai melalui Pendidikan dan Latihan terkait dengan adanya pengembangan pegawai dalam kontek implementasi online system adalah sebagai berikut.
a. Jenis pelatihan
b. Kedalaman pelatihan
c. Sumber daya yang tersedia.
d. Waktu Pelatihan
e. Peserta pelatihan
f. Metode dan media
g. Ketersediaan pemateri/trainer

\section{Kerangka Konseptual}

Kerangka pikir penelitian digambarkan sebagai berikut : 


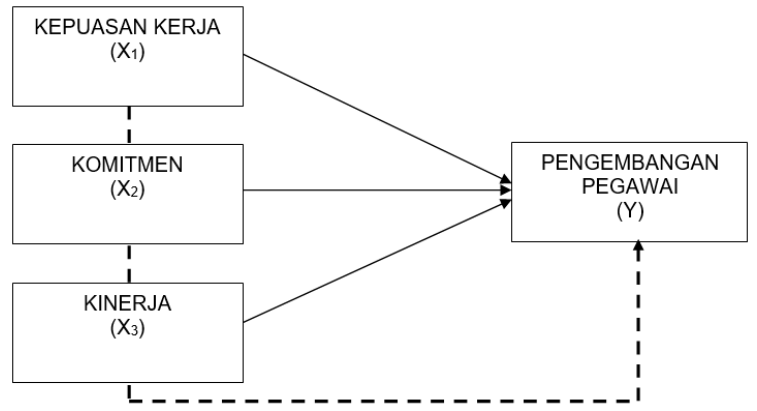

Gambar 3.1. Kerangka Konseptual

Penelitian

Sumber : Hasil Olahan Peneliti, 2019

\section{Hipotesis Penelitian}

Berdasarkan kerangka konseptual penelitian, maka dapat dirumuskan hipotesis sebagai berikut :

1. Kepuasan Kerja berpengaruh secara parsial terhadap pengembangan pegawai pada Badan Pengelolaan Keuangan dan Aset Daerah Kabupaten Tanah Bumbu di Batulicin.

2. Komitmen pegawai berpengaruh secara parsial terhadap pengembangan pegawai dalam kontek implementasi online system pada Badan Pengelolaan Keuangan dan Aset Daerah Kabupaten Tanah Bumbu di Batulicin.

3. Kinerja pegawai berpengaruh secara parsial terhadap pengembangan pegawai dalam kontek implementasi online system pada Badan Pengelolaan Keuangan dan Aset Daerah Kabupaten Tanah Bumbu di Batulicin.

4. Kepuasan Kerja, Komitmen dan Kinerja berpengaruh secara simultan terhadap pengembangan pegawai pada Badan Pengelolaan Keuangan dan Aset Daerah Kabupaten Tanah Bumbu di Batulicin.

\section{Metode Penelitian}

Metode penelitian yang peneliti gunakan adalah Eksplanatori. Populasi penelitian ini adalah seluruh Pegawai Badan Pengelolaan Keuangan dan Aset Daerah Kabupaten Tanah Bumbu sebanyak 40 orang secara total sampling. pengumpulan data dalam peneiitian ini melalui kuesioner, wawancara, dokumentasi dan observasi, analisis data dilakukan secara kuantitatif melalui model dengan menoounakan anlikasi SPSS for windows v. Parsial =

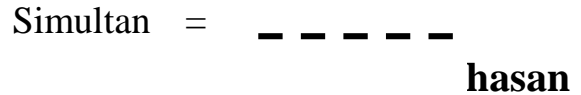

Untuk menganalisis pengaruh Kepuasan Kerja $\left(\mathrm{X}_{1}\right)$, Komitmen $\left(\mathrm{X}_{2}\right)$ dan Kinerja $\left(\mathrm{X}_{3}\right)$, secara simultan mempengaruhi Pengembangan Pegawai (Y) pada Badan Pengelolaan Keuangan dan Aset Daerah Kabupaten Tanah Bumbu. Alat analisis yang dipergunakan pada penelitian ini adalah menggunakan analisis regresi berganda. Alat analisis yang dipergunakan adalah regresi berganda dengan program SPSS Versi 20.0. Pengujian dilakukan dengan tingkat kepercayaan $88 \%$ atau tingkat signifikansi $0,05(\mathrm{a}=0,05)$. Untuk mengkaji kebenaran hipotesis-hipotesis tersebut digunakan analisis linier. Pada analisis regresi ini akan dilakukan uji serentak atau uji F serta parsial atau uji t.

Variabel-variabel yang dianalisis adalah komponen-komponen yang terbentuk dari 2 (dua) komponen yang selanjutnya menjadi variabel. Variabel tersebut adalah : Kepuasan Kerja $\left(\mathrm{X}_{1}\right)$, Komitmen $\left(\mathrm{X}_{2}\right)$ dan Kinerja $\left(\mathrm{X}_{3}\right)$ secara simultan mempengaruhi Pengembangan Pegawai (Y) pada Badan Pengelolaan Keuangan dan Aset Daerah Kabupaten Tanah Bumbu. Hasil perhitungan regresi berganda dapat dilihat pada tabel 5.34 di bawah ini : 
Tabel 5.34

Hasil Output SPSS

Model Summary ${ }^{b}$

\begin{tabular}{|l|c|r|r|r|r|}
\hline Model & $\mathrm{R}$ & $\begin{array}{c}\mathrm{R} \\
\text { Square }\end{array}$ & $\begin{array}{c}\text { Adjusted } \\
\text { R Square }\end{array}$ & $\begin{array}{c}\text { Std. Error } \\
\text { of the } \\
\text { Estimate }\end{array}$ & $\begin{array}{c}\text { Durbin- } \\
\text { Watson }\end{array}$ \\
\hline 1 & $.790^{\mathrm{a}}$ & .624 & .592 & 1.31347 & 2.023 \\
\hline
\end{tabular}

a. Predictors: (Constant), Kinerja, Komitmen, Kepuasan Kerja

b. Dependent Variable: Pengembangan Pegawai

\section{ANOVA $^{\mathrm{b}}$}

\begin{tabular}{|c|c|c|c|c|c|c|}
\hline \multicolumn{2}{|c|}{ Model } & $\begin{array}{l}\text { Sum of } \\
\text { Squares }\end{array}$ & $\mathrm{df}$ & $\begin{array}{c}\text { Mean } \\
\text { Square }\end{array}$ & $\mathrm{F}$ & Sig. \\
\hline 1 & Regression & 102.992 & 3 & 34.331 & 19.899 & $.000^{\mathrm{a}}$ \\
\hline & Residual & 62.108 & 36 & 1.725 & & \\
\hline & Total & 165.100 & 39 & & & \\
\hline
\end{tabular}

a. Predictors: (Constant), Kinerja, Komitmen, Kepuasan Kerja

b. Dependent Variable: Pengembangan Pegawai

Coefficients $^{\mathrm{a}}$

\begin{tabular}{|c|c|c|c|c|c|c|c|}
\hline \multirow[b]{2}{*}{ Model } & \multicolumn{2}{|c|}{$\begin{array}{l}\text { Unstandardized } \\
\text { Coefficients }\end{array}$} & \multirow{2}{*}{$\begin{array}{c}\begin{array}{c}\text { Standardized } \\
\text { Coefficients }\end{array} \\
\text { Beta }\end{array}$} & \multirow[b]{2}{*}{$\mathrm{T}$} & \multirow[b]{2}{*}{ Sig. } & \multicolumn{2}{|c|}{$\begin{array}{l}\text { Collinearity } \\
\text { Statistics }\end{array}$} \\
\hline & B & $\begin{array}{c}\text { Std. } \\
\text { Error }\end{array}$ & & & & Tolerance & VIF \\
\hline $1 \quad$ (Constant) & 4.848 & 2.913 & & 1.664 & .105 & & \\
\hline $\begin{array}{l}\text { Kepuasan } \\
\text { Kerja }\end{array}$ & .561 & .121 & .521 & 4.644 & .000 & .829 & 1.206 \\
\hline Komitmen & -.254 & .191 & -.147 & $\begin{array}{r}- \\
1.332\end{array}$ & .191 & .860 & 1.162 \\
\hline Kinerja & .452 & .109 & .476 & 4.128 & .000 & .786 & 1.273 \\
\hline
\end{tabular}

Pada tabel 5.34 dapat dilihat Adjuster $\left(\mathrm{R}^{2}\right)$ sebesar 0. 592 yang berarti besarnya variasi sumbangan seluruh variabel bebas terhadap variabel terikatnya adalah $59.20 \%$ sedangkan sisanya $40.80 \%$ dijelaskan oleh sebab lain diluar dari penelitian ini (Parasuraman, dalam Tjiptono, 2015 : 112).

Berdasarkan tabel 5.34 diperoleh persamaan regresi sebagai berikut. :
$Y=4.848+0,561 X_{1}+-0,253 X_{2}+452 X_{3}+e$

Berdasarkan persamaan tersebut, menunjukkan bahwa semua variabel bebas memiliki koefisien regresi positif.Hal ini berarti variabel Kepuasan Kerja $\left(\mathrm{X}_{1}\right)$, Komitmen $\left(\mathrm{X}_{2}\right)$ dan Kinerja $\left(\mathrm{X}_{3}\right)$ mempunyai hubungan yang searah atau berbanding lurus dengan variabel terkaitnya atau terhadap Pengembangan Pegawai di Wilayah Kerja Badan Pengelolaan Keuangan dan Aset Daerah Kabupaten Tanah Bumbu. Artinya, jika variabel $\mathrm{X}_{1}, \mathrm{X}_{2}$ dan mengalami kenaikan maka variabel terikatnya $\mathrm{Y}$ juga ikut mengalami kenaikan, dan jika variabel $\mathrm{X}_{1}, \mathrm{X}_{2}$ mengalami penurunan, maka variabel terkaitnya $\mathrm{Y}$ akan mengalami penurunan.

1. Harga koefisien konstanta $=4.848$. Hal ini berarti apabila nilai dari $\mathrm{X}_{1}$ dan $\mathrm{X}_{2}$ di objek penelitian sama dengan 0 , maka tingkat atau besarnya variabel dependent Y dilokasi tersebut akan sebesar 4.848.

2. Harga koefisien $b_{1}=0.561$ berarti bahwa apabila nilai $X_{1}$ mengalami perubahan (kenaikan atau penurunan), sementara variabel lainnya bersifat tetap, maka tingkat variabel $Y$ (Pengembangan Pegawai) di Wilayah Kerja Badan Pengelolaan Keuangan dan Aset Daerah Kabupaten Tanah Bumbu Kerja obyek penelitian tersebut akan meningkat.

3. Harga koefisien $b_{2}=-0.253$ berarti bahwa apabila nilai $\mathrm{X}_{2}$ mengalami perubahan (kenaikan atau penurunan), sementara variabel lainnya bersifat tetap, maka tingkat variabel Y (Pengembangan Pegawai) di Wilayah Kerja Badan Pengelolaan Keuangan dan Aset Daerah Kabupaten Tanah Bumbu Kerja penelitian tersebut akan meningkat.

4. Harga koefisien $b_{3}=0.452$ berarti bahwa apabila nilai $X_{3}$ mengalami 
perubahan (kenaikan atau penurunan), sementara variabel lainnya bersifat tetap, maka tingkat variabel Y (Pengembangan Pegawai) di Wilayah Kerja Badan Pengelolaan Keuangan dan Aset Daerah Kabupaten Tanah Bumbu penelitian tersebut akan meningkat.

Untuk melihat jelasnya pengaruh Kepuasan Kerja $\left(\mathrm{X}_{1}\right)$, Komitmen $\left(\mathrm{X}_{2}\right)$ dan Kinerja terhadap Pengembangan Pegawai Pegawai Badan Pengelolaan Keuangan dan Aset Daerah Kabupaten Tanah Bumbu diuraikan sebagai berikut.

1. Pengaruh Kepuasan Kerja Terhadap Pengembangan Pegawai di Badan Pengelolaan Keuangan dan Aset Daerah Kabupaten Tanah Bumbu

Pengaruh variabel (X) meliputi Kepuasan Kerja $\left(\mathrm{X}_{1}\right)$ terhadap variabel Pengembangan Pegawai (Y) pada Badan Pengelolaan Keuangan dan Aset Daerah Kabupaten Tanah Bumbu dapat dijelaskan mengenai pengujian hipotesis. Untuk menguji pengaruh variabel bebas yakni Kepuasan $\operatorname{Kerja}\left(\mathrm{X}_{1}\right)$ terhadap variabel tergantung (Y) dengan menggunakan Uji Parsial (Uji t). Langkah awal yang harus dilakukan adalah membandingkan antara nilai t-hitung (th) dengan nilai t-tabel (tt) pada taraf nyata (5\%).

Berdasarkan Tabel 5.34 dapat dijelaskan bahwa variabel Kepuasan Kerja yang mempunyai nila t-hitung > nilai t-Tabel berarti bahwa variabel tersebut pada taraf nyata (5\%) mempunyai pengaruh yang bermakna terhadap Pengembangan Pegawai pada Badan Pengelolaan Keuangan dan Aset Daerah Kabupaten Tanah Bumbu Nilai t-hitung untuk Kepuasan Kerja 4.644> tTabel sebesar 1.683 dengan probabilitas sebesar .000 lebih rendah dari $\alpha=0,05$ atau lebih kecil dari taraf nyata $5 \%$.
Hal ini menunjukkan bahwa Pengaruh Kepuasan Kerja $\left(\mathrm{X}_{1}\right)$ terhadap Pengembangan Pegawai pada Badan Pengelolaan Keuangan dan Aset Daerah Kabupaten Tanah Bumbu adalah signifikan.

Koefisien regresi Kepuasan Kerja $\left(\mathrm{X}_{1}\right)$ adalah sebesar .521, hal ini menunjukkan Pengaruh positif atau searah dengan Pengembangan Pegawai pada Badan Pengelolaan Keuangan dan Aset Daerah Kabupaten Tanah Bumbu (Y) Artinya apabila Kepuasan Kerja dilandasi pula dengan balas jasa yang adil dan layak, penempatan yang sesuai dengan keahlian, berat ringannya pekerjaan, suasana dan lingkungan pekerjaan, peralatan yang menunjang dan motivasi pimpinan dalam kepemimpinannya maka Pengembangan Pegawai pada Badan Pengelolaan Keuangan dan Aset Daerah Kabupaten Tanah Bumbu (Y) akan kurang meningkat dengan baik. Angka $\mathrm{r}^{2}$ untuk faktor nilai adalah .521 artinya bahwa kontribusii Kepuasan Kerja terhadap Pengembangan Pegawai pada Badan Pengelolaan Keuangan dan Aset Daerah Kabupaten Tanah Bumbu adalah 52\%, dengan catatan faktor lain adalah konstan. Dengan demikian adanya Kepuasan Kerja dapat memberikan Pengembangan Pegawai yang baik bagi Pegawai Badan Pengelolaan Keuangan dan Aset Daerah Kabupaten Tanah Bumbu.

2. Pengaruh Komitmen Terhadap Pengembangan Pegawai di Badan Pengelolaan Keuangan dan Aset Daerah Kabupaten Tanah Bumbu

Pengaruh variabel $(\mathrm{X})$ meliputi $\operatorname{Komitmen}\left(\mathrm{X}_{2}\right)$ terhadap variabel Pengembangan Pegawai pada Pegawai Badan Pengelolaan Keuangan dan Aset Daerah Kabupaten Tanah Bumbu (Y) dapat dijelaskan mengenai pengujian 
hipotesis. Untuk menguji pengaruh variabel bebas yakni Komitmen $\left(\mathrm{X}_{2}\right)$ terhadap variabel tergantung (Y) dengan menggunakan Uji Parsial (Uji t).Langkah awal yang harus dilakukan adalah membandingkan antara nilai thitung (th) dengan nilai $t$-tabel (tt) pada taraf nyata $(5 \%)$.

Berdasarkan Tabel 5.34 dapat dijelaskan bahwa variabel Komitmen yang mempunyai nilai $\quad t$-hitung $<$ nilai $t-$ Tabel berarti bahwa variabel tersebut pada taraf nyata $(5 \%)$ mempunyai pengaruh yang bermakna terhadap Pengembangan Pegawai pada Badan Pengelolaan Keuangan dan Aset Daerah Kabupaten Tanah Bumbu Nilai t-hitung untuk Komitmen -1.332> t-Tabel sebesar 1.683 dengan probabilitas sebesar .191 lebih tinggi dari $\alpha=0,05$ atau lebih besar dari taraf nyata 5\%. Hal ini menunjukkan bahwa Pengaruh Komitmen $\quad\left(\mathrm{X}_{2}\right) \quad$ terhadap Pengembangan Pegawai pada Pegawai Badan Pengelolaan Keuangan dan Aset Daerah Kabupaten Tanah Bumbu adalah tidak signifikan.

Koefisien regresi Komitmen $\left(X_{2}\right)$ adalah sebesar .-147, hal ini menunjukkan Pengaruh positif atau searah dengan Pengembangan Pegawai pada Pegawai Badan Pengelolaan Keuangan dan Aset Daerah Kabupaten Tanah Bumbu (Y) Artinya apabila Komitmen dilandasi dengan penggunaan waktu dalam tugas, perhatian terhadap tugas dan perhatian terhadap publik maka Pengembangan Pegawai pada Badan Pengelolaan Keuangan dan Aset Daerah Kabupaten Tanah Bumbu (Y) akan kurang meningkat dengan baik. Angka $\mathrm{r}^{2}$ untuk faktor nilai adalah -.147 artinya bahwa kontribusi Komitmen terhadap Pengembangan Pegawai pada Badan Pengelolaan Keuangan dan Aset Daerah
Kabupaten Tanah Bumbuadalah -14\%, dengan catatan faktor lain adalah konstan. Dengan demikian adanya Komitmen dapat memberikan Pengembangan Pegawai yang kurang baik bagi Pegawai Badan Pengelolaan Keuangan dan Aset Daerah Kabupaten Tanah Bumbu.

3. Pengaruh Kinerja Terhadap Pengembangan Pegawai di Badan Pengelolaan Keuangan dan Aset Daerah Kabupaten Tanah Bumbu

Pengaruh variabel $(\mathrm{X})$ meliputi Kinerja $\left(\mathrm{X}_{3}\right)$ terhadap variabel Pengembangan Pegawai pada Badan Pengelolaan Keuangan dan Aset Daerah Kabupaten Tanah Bumbu (Y) dapat dijelaskan mengenai pengujian hipotesis. Untuk menguji pengaruh variabel bebas yakni Kinerja $\left(\mathrm{X}_{3}\right)$ terhadap variabel tergantung (Y) dengan menggunakan Uji Parsial (Uji t). Langkah awal yang harus dilakukan adalah membandingkan antara nilai thitung (th) dengan nilai $t$-tabel (tt) pada taraf nyata $(5 \%)$.

Berdasarkan Tabel 5.34 dapat dijelaskan bahwa variabel Kinerja yang mempunyai nila $t$-hitung $>$ nilai $t$-Tabel berarti bahwa variabel tersebut pada taraf nyata $(5 \%)$ mempunyai pengaruh yang bermakna terhadap Pengembangan Pegawai pada Badan Pengelolaan Keuangan dan Aset Daerah Kabupaten Tanah Bumbu Nilai t-hitung untuk Kinerja 4.128> t-Tabel sebesar 1.683 dengan probabilitas sebesar 0,000 lebih rendah dari $\alpha=0,05$ atau lebih kecil dari taraf nyata $5 \%$. Hal ini menunjukkan bahwa Pengaruh Kinerja $\left(X_{3}\right)$ terhadap Pengembangan Pegawai pada Badan Pengelolaan Keuangan dan Aset Daerah Kabupaten Tanah Bumbu adalah signifikan.

Koefisien regresi Kinerja $\left(\mathrm{X}_{3}\right)$ adalah sebesar .476, hal ini 
menunjukkan Pengaruh positif atau searah dengan Pengembangan Pegawai Pegawai Badan Pengelolaan Keuangan dan Aset Daerah Kabupaten Tanah Bumbu (Y) Artinya apabila Kinerja dilandasi pula dengan kualitas kerja, kuantitas kerja, pengetahuan, keandalan, kehadiran dan kerjasama maka Pengembangan Pegawai Badan Pengelolaan Keuangan dan Aset Daerah Kabupaten Tanah Bumbu (Y) akan meningkat dengan baik. Angka $\mathrm{r}^{2}$ untuk faktor nilai adalah .476 artinya bahwa kontribusi Kinerja terhadap Pengembangan Pegawai Badan Pengelolaan Keuangan dan Aset Daerah Kabupaten Tanah Bumbu adalah 47\%, dengan catatan faktor lain adalah konstan. Dengan demikian adanya Kinerja dapat memberikan Pengembangan Pegawai yang baik bagi Pegawai Badan Pengelolaan Keuangan dan Aset Daerah Kabupaten Tanah Bumbu.

4. Pengaruh Kepuasan Kerja, Komitmen dan Kinerja Secara Bersama-Sama Terhadap Pengembangan Pegawai Badan Pengelolaan Keuangan Dan Aset Daerah Kabupaten Tanah Bumbu

Berdasarkan hasil penghitungan model persamaan regresi linier berganda di atas menunjukkan antara Kepuasan Kerja $\left(\mathrm{X}_{1}\right)$, Komitmen $\left(\mathrm{X}_{2}\right)$ dan Kinerja $\left(\mathrm{X}_{3}\right)$ secara simultan mempengaruhi Pengembangan Pegawai (Y) pada Badan Pengelolaan Keuangan dan Aset Daerah Kabupaten Tanah Bumbu sebagai variabel bebas mempunyai pengaruh positif. Pengaruh tersebut menunjukkan bahwa ketiga faktor sebagai variabel bebas berubah searah dengan perubahan Pengembangan Pegawai sebagai variabel tidak bebas.Kemudian untuk mengetahui Kepuasan Kerja $\left(\mathrm{X}_{1}\right)$, Komitmen $\left(\mathrm{X}_{2}\right)$ dan Kinerja $\left(\mathrm{X}_{3}\right)$ berpengaruh terhadap variabel (Y) yakni Pengembangan Pegawai pada Badan Pengelolaan Keuangan dan Aset Daerah Kabupaten Tanah Bumbu dapat dilakukan Uji F.

Dengan Uji Serentak (Uji F) digunakan untuk membuktikan atau menguji kebenaran hipotesis pertama yang akan diajukan dalam penelitian initerdiri Kepuasan Kerja $\left(\mathrm{X}_{1}\right)$, Komitmen $\left(\mathrm{X}_{2}\right)$ dan Kinerja $\left(\mathrm{X}_{3}\right)$ secara serentak berpengaruh terhadap Pengembangan Pegawai Badan Pengelolaan Keuangan dan Aset Daerah Kabupaten Tanah Bumbu.

Berdasarkan Uji serentak (Uji F) mengenai Kepuasan Kerja dan Komitmen terhadap Pengembangan Pegawai pada Badan Pengelolaan Keuangan dan Aset Daerah Kabupaten Tanah Bumbu ini dilakukan dengan membandingkan $\mathrm{F}$ hitung dengan $\mathrm{F}$ Tabel pada taraf nyata $\alpha=0,05$. Dari hasil perhitungan data dari Output SPSS 20.0 terlihat pada tabel tersebut di atas dapat dilihat bahwa nilai $F$ hitung $19.899>\mathrm{F}$ Tabel 2.45 dengan probabilitas sebesar 0,000, hal ini berarti bahwa pada taraf nyata $\alpha=0,05$ dapat dikatakan Kepuasan Kerja $\left(\mathrm{X}_{1}\right)$, Komitmen $\left(\mathrm{X}_{2}\right)$ dan Kinerja $\left(\mathrm{X}_{3}\right)$ mempunyai pengaruh yang berarti terhadap Pengembangan Pegawai pada Badan Pengelolaan Keuangan dan Aset Daerah Kabupaten Tanah Bumbu atau dengan perkataan lain bahwa dengan taraf nyata $5 \%$, hipotesis pertama diterima (terbukti).

Sedangkan Angka Multiple R adalah.790 artinya bahwa pengaruh faktor Kepuasan Kerja $\left(\mathrm{X}_{1}\right)$, Komitmen $\left(\mathrm{X}_{2}\right)$ dan Kinerja $\left(\mathrm{X}_{3}\right)$ terhadap Pengembangan Pegawai pada Badan Pengelolaan Keuangan dan Aset Daerah Kabupaten Tanah Bumbu sebesar $79.00 \%$. 
Sedangkan Koefisien $\mathrm{R}^{2}$ mengukur proporsi atau prosentasi total variasi dalam Pengembangan Pegawai sebagai variabel Y yang dijelaskan oleh model regresi pada variabel $\mathrm{X}$ yakni Kepuasan Kerja dan Komitmen. Terlihat Koefisien determinasi bergerak dari 0 sampai 1, karena memiliki angka/nilai.0.624 berarti semakin mendekati 1, dalam artian faktor Kepuasan Kerja $\left(\mathrm{X}_{1}\right)$, Komitmen $\left(\mathrm{X}_{2}\right)$ dan Kinerja $\left(\mathrm{X}_{3}\right)$ memberikan pengaruh yang signifikan terhadap Pengembangan Pegawai.

Dalam mencapai kinerja yang tinggi menurut Hasibuan (2010:42) sangat dipengaruhi adanya kepuasan dan komitmen yang diberikan sebagai upaya pencapaian tujuan harus dipandang sebagai suatu proses. Pelaksanaan yang efektif dan efisien, bagaimanapun Baiknya suatu program apabila tidak dilaksanakan secara efektif dan efisien maka organisasi tersebut tidak akan mencapai sasarannya, karena dengan pelaksanaan organisasi semakin didekatkan pada tujuannya. Oleh karena itu, agar pencapaian tujuan akhir semakin terjamin, diperlukan pentahapan, Baik dalam arti pentahapan pencapaian bagian-bagiannya maupun pentahapan dalam arti periodisasinya. Pencapaian tujuan terdiri dari beberapa faktor, yaitu: kurun waktu dan sasaran yang merupakan target kongkrit yang ada di dalam hal ini dijelaskan bahwa sumber daya manusia sangat berpengaruh dan memiliki peran peting di Reskrimum Polda Kalimantan Selatan. SDM yang Baik mampu membawa organisasi tersebut ke arah tujuan yang lebih Baik.

Perkembangan kemajuan

Pembinaan atas pegawa yang cukup pesat, seiring dengan merebaknya fenomena supremasi hukum, hak asasi manusia, globalisasi, demokratisasi, desentralisasi, transparansi, akuntabilitas, telah melahirkan sebagai paradigma baru dalam melihat tujuan, tugas, fungsi, wewenang dan tanggung jawab ASN yang selanjutnya menyebabkan terhadap pelaksanaan tugas ASN yang meningkat dan lebih berorientasi kepada masyarakat yang dilayani.

Sebagaimana ditegaskan dalam rumusan tugas, fungsi dan peran ASN serta pemisahan kelembagaan Tentara Nasional Indonesia dan ASN sesuai dengan peran dan fungsi masingmasingkepada paradigma baru sehingga diterapkan agar lebih dapat memantapkan kedudukan dan peranan serta pelaksanaan tugas ASN sebagai bagian integral dari reformasi meyeluruh segenap tatanan madani yang adil, makmur, dan beradab berdasarkan Pancasila dan UndangUndang Dasar Negara Republik Indonesia Tahun 1945.

Asas legalitas sebagai aktualitas paradigma supremasi hukum, kewenangan ASN, yaitu melakukan penyelidikan dan penyidikan terhadap semua tindak pidana sesuai dengan hukum acara pidana dan peraturan perundang-undangan lainnya. Namun tindakan pencegahan tetap diutamakan melalui pengembangan asas preventif dan asas kewajiban umum kepolisian, yaitu memelihara keamanan dan ketertiban masyarakat. Dalam hal ini setiap pejabat ASN memiliki kewenangan diskresi, yaitu kewenangan untuk bertindak demi kepentingan umum berdasarkan penilaian sendiri.

Oleh karena itu undang-undang ini mengatur pula pembinaan profesi dan kode etik profesi agar tindakan pejabat ASN dapat dipertanggungjawabkan, Baik secara 
hukum, moral maupun secara teknik profesi dan terutama hak asasi manusia. Begitu pentingnya perlindungan dan kemajuan hak asasi manusia kerana menyangkut harkat dan martabat manusia, Negara Republik Indonesia telah membentuk Undang-Undang Nomor 5 Tahun 1998 tentang Ratifikasi Konvensi Menentang Penyiksaan dan Perlakuan atau Penghukuman Lain yang Kejam, Tidak Manusiawi atau Merendahkan Martabat Manusia, Undang-Undang Nomor 26 Tahun 2000 tentang Pengadilan Hak Asasi Manusia.

Setiap anggota ASN wajib memedomani dan menaati ketentuan undang-undang. Substansi lain yang baru dalam undang-undang ini adalah diaturnya lembaga kepolisian nasional yang tugasnya memberi saran kepada Presiden tentang arah kebijakan kepolisian dan pertimbangan dalam pengangkatan dan pemberhentian Kapolri sesuai amanat Ketetapan MPR RI No. VII/MPR/2000, selain terkandung pula fungsi pengawasan fungsional terhadap Pengembangan Pegawai ASN sehingga kemandirian dan profesionalisme ASN dapat terjamin.

Reskrimum Polda Kalimantan Selatan dalam menjalankan kebijaksanannya kewenangan dalam pelaksanaannya patut dijalankan. Sebagai tindak lanjutnya selaku pelaksana kebijaksanaan untuk mengevaluasi terhadap hasil kebijaksanaan yang telah diambilnya.

Namun demikian menurut anggapan peneliti langkah-langkah yang telah diakukan oleh Kepala Badan selaku pembina petugas yang telah ditempuh oleh walaupun berjalan Baik, namun demikian perlu memberikan pengarahan, bimbingan, pendidikan dan Kepuasan Kerja juga disiplin kerja dinilai sebagai langkah yang Baik. Dengan tetap mengembangkan kualitas kerja serta menumbuhkan rasa disiplin pribadi dalam setiap pertemuan dengan harapan akan tumbuh kesadaran dalam diri pribadi pegawai ketauladanan murni.

Pendidikan dihubungkan dengan peningkatan pengetahuan umum dan pemahaman akan seluruh lingkungan disekitar kita, sedangkan Kepuasan Kerja adalah suatu kegiatan untuk meningkatkan ilmu pengetahuan dan keterampilan pegawai dalam pekerjaan yang biasa dilakukan sehari-hari.

Jalur pendidikan formal memberikan dasar-dasar teori, logika dan kemampuan analisa, pengetahuan umum, pengembangan bakat, kepribadian dan sikap mental, sedangkan jalur Kepuasan Kerja menekankan pada aspek kemampuan, keahlian, keterampilan kektik dan profesionalisme yang dikaitkan dengan pekerjaan dan persyaratan kerja. Berdasarkan sifatnya, kepuasan kerja bersifat praktis (spesialis), pendidikan bersifat teoritis (generalis). Walaupun terdapat perbedaan antara pendidikan dan kepuasan kerja, tetapi pada dasarnya mempunyai tujuan yang sama, yakni untuk meningkatkan keterampilan (skill) dan pengetahuan (knowledge).

Observasi yang telah dilakukan oleh peneliti bahwa SDM (Pegawai Reskrimum Polda Kalimantan Selatan) memiliki posisi sangat strategis dalam organisasi, artinya manusia memegang peranan penting dalam melakukan aktivitas untuk mencapai tujuan dan kondisi yang lebih baik maka perlu adanya manajemen terhadap SDM secara memadai, sehingga terciptalah SDM yang berkualitas, loyal dan berprestasi. MSDM merupakan usaha untuk mengerahkan dan mengelola 
sumber daya manusia didalam organisasi agar mampu berpikir dan bertindak sebagaimana yang diinginkan oleh organisasi.

\section{Kesimpulan}

Berdasarkan pada hasil analisis dan pembahasan pada bab sebelumnya, maka penelitian ini dapat ditarik beberapa simpulan sebagai berikut.

1. Secara parsial kepuasan kerja berpengaruh terhadap pengembangan pegawai pada Badan Pengelolaan Keuangan dan Aset Daerah Kabupaten Tanah Bumbu di Batulicin.

2. Secara parsial komitmen pegawai berpengaruh terhadap pengembangan pegawai dalam kontek implementasi online system pada Badan Pengelolaan Keuangan dan Aset Daerah Kabupaten Tanah Bumbu di Batulicin.

3. Secara parsial kinerja pegawai berpengaruh terhadap pengembangan pegawai dalam kontek implementasi online system pada Badan Pengelolaan Keuangan dan Aset Daerah Kabupaten Tanah Bumbu di Batulicin.

4. Secara simultan dari persamaan regresi dapat dikemukakan bahwa Kepuasan Kerja $\left(\mathrm{X}_{1}\right)$, Komitmen $\left(\mathrm{X}_{2}\right)$ dan Kinerja $\left(X_{3}\right)$ terhadap Pengembangan Pegawai Pegawai Badan Pengelolaan Keuangan dan Aset Daerah Kabupaten Tanah Bumbu menunjukan pengaruh yang signifikan karena Berdasarkan hasil uji $\mathrm{F}$ diketahui bahwa $\mathrm{F}$ hitung $>\mathrm{F}$ Tabel. Atau dengan angka $\mathrm{F}$ hitung 19.899> $\mathrm{F}$ Tabel 2.45 sehingga hipotesis terbukti kebenarannya.

Memperhatikan kesimpulan penelitian ini, akhirnya dapat dikemukakan beberapa saran yang berkaitan dengan hasil penelitian dengan uraian sebagai berikut.

1. Perlu adanya kepuasan kerja yang efektif dari Kepala Badan Pengelolaan
Keuangan dan Aset Daerah Kabupaten Tanah Bumbu kepada pegawai yang diberdayakan agar memiliki jalinan sama yang tinggi sehingga mampu saling menjalankan tugas kelas sesuai tugas dan fungsi.

2. Perlu ditingkatkan komitmen bagi pegawai Badan Pengelolaan Keuangan dan Aset Daerah Kabupaten Tanah Bumbu sehingga dapat dikalkulasikan besarnya volume dengan yang diberdayakan agar dapat berjalan dengan efektif.

3. Perlu ditingkatkan kesesuaian antara jabatan yang diperoleh dengan bidang kerja apabila ditentukan dengan adanya pekerjaan baru maka mudah menyesuaikan perubahan sehingga dapat menjadi acuan atau petunjuk yang jelas berupa daftar isian yang digunakan untuk menilai keberhasilan pelaksanaan kerja yang ada pada Badan Pengelolaan Keuangan dan Aset Daerah Kabupaten Tanah Bumbu.

4. Perlu adanya penilaian pengembangan pegawai secara objektif dari masyarakat atau pihak yang berkompeten untuk mengetahui secara jelas tingkat keberhasilan pembinaan yang dilakukan oleh pegawai Badan Pengelolaan Keuangan dan Aset Daerah Kabupaten Tanah Bumbu.

5. Perlu kelonggaran dari pimpinan untuk memberikan kesempatan pada pegawai untuk meningkatkan kualitasnya melalui pendidikan formal untuk ditempatkan pada jabatan yang sesuai dengan profesionalisme kerjanya.

\section{Daftar Pustaka}

Arikunto, Suharsimi, 2010. Prosedur Penelitian : Suatu Pendekatan Praktik, Edisi. Revisi VI, Jakarta : PT Rineka Cipta 
As'ad, Moch. 2011. Seri Ilmu Manajemen Sumber Daya Manusia. Psikologi Industri. Yogyakarta : Liberty.

Bambang Wahyudi, 2012. Manajemen Sumber Daya Manusia. Sulita, Bandung

Baron \& Greenberg. 2010. Behavior in Organization Understanding and Managing The. Human Side of Work. 6th edition. USA: Prentice Hall.

Bontaraswaty, 2011. Pengaruh Adaptas i kebijakan Mengenai Work Family Issue Terhadap Absen Dan Turnover. Jurnal Managemen UGM, hal. 85-95.

Byars, Llloyd L dan Rue, Leslie W. 2008. Human Resource Management. 8 edition. MCGraw-Hill, Irwin

Cahyono, Tri, Bambang. 2012. Manajemen Sumber Daya Manusia. Jakrta : IPWI

Diawati, Mawadha, Kestari Prety dan Sugesti. Hesty 2015. Pengaruh Pengembangan Karier Terhadap Kepuasan Kerja Pegawai. Studi Kasus Di PT. Pelabuhan Indonesia II. Persero) Cabang Cirebon). Jurnal Ilmiah Online

Fathoni Abdurrahmat, 2006. Manajemen Sumber Daya Manusia. Bandung: Rineka Cipta

Ferdinand, Augusty. 2014. Metode Penelitian Manajemen. BP Universitas. Diponegoro. Semarang

Ghozali, Imam dan Ratmono, Dwi. 2011. Analisis Multivariat dan Ekonometrika dengan Eviews 10. Badan Penerbit Universitas Diponegoro: Semarang

Ghozali, Syaidam, 2013. Manajemen Sumber Daya Manusia ( Pendekatan Mikro). Jakarta : Djambatan

Glickman, C.D., Gordon, S.P., and RossGordon, J.M. 2008. Supervisionand Instructional
Leadership A Development Approach. Seventh Edition. Boston: Perason

Griffin, Ricky W., and Moorhead, Gregory., 2010. Organizational Behavior: Managing People and Organizations. Eleventh Edition. USA: South. Western

Hadari Nawawi, 2010. Metode Penelitian Bidang Sosial. Yogyakarta: Gajah. Mada University Press

Handoko, T. Hani, 2010. Manajemen Personalia \& Sumber daya Manusia. BPFE-Yogyakarta

Hariandja Marihot Tua Efendi. 2007. Manajemen Sumber Daya Manusia. Jakarta: PT.Grasindo

Hasibuan, Melayu S.P., 2012. Pengembangan dan Manajemen Sumber Daya Manusia. Jakarta : Bumi Aksara

Hasibuan, S, Melayu. 2010. Manajemen Sumber Daya Manusia ( Pendekatan Mikro). Jakarta : Bumi Aksara.

Irham Fahmi, 2010. Analisis Laporan Keuangan. Bandung: Alfabeta

Kartono, Kartini. 2010. Pemimpin dan Kepemimpinan. Jakarta : CV Rajawali

Katili, A. S. 2010. Struktur Komunitas Echinodermata Pada Zona Intertidal Di Gorontalo. Jurnal Penelitian dan Pendidikan, Volume 8 Nomor 1, Maret 2011, 51-61.

Laksana, Ronna. 2014. Pengaruh Gaya Kepemimpinan terhadap Kinerja. Karyawan Bagian Marketing pada PT. Bank Muamalat, Tbk. Cabang. Tasikmalaya

Lukman Haris. 2010. Naskah Publikasi: Hubungan Antara Kepuasan Kerja Dengan Komitmen Organisasi pada Pegawai Negeri Sipil. Yogyakarta: Tidak Diterbitkan

Luthans, 2012, Perilaku Organisasi. Edisi Sepuluh, PT. Andi: Yogyakarta 
Manullang, 2011. Dasar-Dasar Manajemen, edisi revisi, cetakan ketujuh, Penerbit : Ghalia Indonesia, Jakarta

Martoyo, Soesilo. 2010. Manajemen Sumber Daya Manusia. Yogyakarta : PT BPFE

Mayfi, F., dan Rudianto, D. 2014. Analisis Pengaruh Faktor Internal Dan Eksternal Perusahaan Terhadap ReturnSaham. Jurnal MIX, Vol. IV, No. 3, Hal 348 -362.

Narimawati, 2010. Riset Manajemen Sumber Daya Manusia Aplikasi Contoh \& Perhitungannya. Jakarta: Agung Media.

Nasution, 2009. Metode Research (Penelitian Ilmiah). Jakarta: Bumi Aksara

Nasution. 2007. Budaya Organisasi, Kepuasan Kerja, Komitmen Organisasional, dan Keinginan Berpindah : Investigasi Empiris Pada Berbagai Unit Kerja di Universitas Bengkulu". Jurnal bisnis dan Ekonomi Vol. 13 no 2

Nawawi, 2010. Manajemen Sumber Daya Manusia untuk Bisnis yang. Kompetitif.Cetakan Keempat. Penerbit Gadjah Mada University Press,. Yogyakarta

Notoatmodjo, 2014. Ilmu kinerja pegawai dan masyarakat prinsip - prinsip dasar. Rineka cipta : Jakarta

Notoatmodjo, $\quad$ Soekidjo. 2014. Pengembangan Sumber Daya Manusia. Jakarta : Rineka Cipta.

Prahartanto, Adhie, 2012. Dimansi dan indikator variabel (http://adieprahartanto.blogspot.c o.id/2012/08/kumpulan-variabeldimensi-dan-indikator_28.html) diakses pada 28 oktober 2016 pada jam $12.11 \mathrm{wib}$

Rivai, Veithzal, 2010. Manajemen Sumber Daya Manusia untuk Perusahaan : dari Teori Ke Praktik, Edisi
Pertama, Penerbit PT. Raja Grafindo Persada,. Jakarta

Robbins, F, Stephen. 2012. Perilaku Organisasi. Jakarta : Gramedia

Salma, D. 2016 Pengaruh Komitmen Organisasi, Motivasi Kerja Dan Pengalaman Kerja Terhadap Kinerja Pegawai Honor Lepas Pada Puskesmas Di Kabupaten Morowali e Jurnal Katalogis, Volume 4 Nomor 8, Agustus 2016 hlm 73-84

Sedarmayanti. 2011. Sumber Daya Manusia dan Produktivitas Kerja. Bandung CV Mandar Maju

Setiawati, Devi, Zilkaida, Anita. 2012. Perbedaan Komitmen Kerja Berdasarkan Orientasi Peran Gender Pada Karyawan Di Bidang Kerja Non Tradisional. Proceeding PESAT Vol.2.

Siagian, Sondang, P. 2012. Manajemen Sumber Daya Manusia. Jakarta : Bumi Aksara

Simamora, Hanry. 2010. Manajemen Sumber Daya Manusia Yogyakata: STIE YKPN

Sinambela, Lijan Poltak. 2012. Kinerja Pegawai. Graha Ilmu: Yogyakarta

Sopiah, 2010. Perilaku Organisasi, Yogyakarta: Andi Offset.

Sunarto, 2012. Manajemen Sumber Daya Manusia Strategik. Yogyakarta: Amus

Sutrisno, Edy. 2010. komitmen dan Budaya Organisasi. Jakarta: Kencana

Syah, Haikal, Auzan, Syaharudin, M dan Nurhardjom Budi.2017. Pengaruh Pengembangan Karier dan Penilaian Kinerja terhadap Kepuasan Kerja Melalui Komitmen Kerja Pegawai Koperasi Agrobisnis Tarutama Nusantara Jember. Journal Ekonomi Bisnis dan Akuntansi, 2018, Volume V. 2) :158-163

Thoha, Miftah. 2010. Lingkungan kerja Organisasi Proses Diagnosa dan 
Intervensi. PT. Grafindo Persada. Jakarta.

Thoha, Miftah. 2012. Manajemen Organisasi dan Lingkungan Kerja. PT. Grafindo Persada. Jakarta.

Wahjosumidjo, 2012. Kepemimpinan dan Motivasi. Jakarta: Galia Indonesia

Wahyudi, Bambang. 2012. Manajemen Sumber Daya Manusia. Bandung : Sulita

Wibowo, A, 2010. Manajemen Kinerja. Jakarta : Rineka Cipta

Wijaja, 2012. Komunikasi dan Hubungan Masyarakat. Jakarta : PT. Bumi. Aksara

Wursanto, 2010. Dasar-Dasar Ilmu Organisasi, Andi Offset, Yogyakarta

Yaumi, Muhammad. \& Damopolii, Muljono. 2014. Action Research: Teori, Model, dan Aplikasi.Jakarta : Kencana 